\title{
EFEKTIVITAS PENERAPAN PROGRAM E-KELURAHAN DI KELURAHAN SILAING BAWAH KOTA PADANG PANJANG
}

\author{
EFFECTIVENESS OF THE IMPLEMENTATION E-KELURAHAN \\ PROGRAM KELURAHAN SILAING BAWAH KOTA PADANG PANJANG
}

\author{
Fristiza Dwi Tami dan Nora Eka Putri \\ Jurusan Ilmu Administrasi Negara, Fakultas Ilmu Sosial \\ Universitas Negeri Padang \\ tizadt@gmail.com, noraekaputri@fis.unp.ac.id
}

\begin{abstract}
Abstrak
Penelitian yang dilakukan ini beranjak dari adanya permasalahan dalam penerapan program $e$-kelurahan, dimana dalam penerapannya masih banyak masyarakat yang belum memanfaatkan program $e$-kelurahan untuk mengurus keperluan administrasinya. Penelitian ini bertujuan untuk mengetahui Efektivitas penerapan program $e$-kelurahan di Kelurahan Silaing Bawah Kota Padang Panjang dalam memberikan pelayanan kepada masyarakat, apa saja kendala yang dihadapi dalam penerapan program $e$-kelurahan di Kelurahan Silaing Bawah Kota Padang Panjang, serta upaya yang dilakukan dalam mengatasi kendala yang dihadapi. Metode penelitian yang digunakan adalah metode penelitian deskriptif kualitatif. Sumber data yang digunakan adalah data primer dan data sekunder yang diperoleh melalui wawancara dan studi dokumentasi. Uji keabsahan data dilakukan dengan teknik triangulasi data. Adapun hasil penelitian ini menunjukkan bahwa secara keseluruhan, efektivitas penerapan progam $e$-kelurahan di Kelurahan Silaing Bawah Kota Padang Panjang berdasarkan indikator pemahaman program, tepat sasaran, tepat waktu, tercapainya tujuan, dan perubahan nyata sudah berjalan dengan baik, namun belum sepenuhnya efektif. Hal ini dilihat dari kurangnya sosialisasi yang dilakukan kepada pegawai kantor kelurahan maupun kepada masyarakat itu sendiri serta kurangnya pemanfaatan program $e$-kelurahan oleh masyarakat. Adapun kendala yang dihadapi yaitu kurangnya pengaplikasian program oleh pegawai kantor serta kurangnya kepuasan masyarakat terhadap program. Dan untuk mengatasi kendala tersebut, Pemerintah akan melakukan sosialisasi lebih lanjut lagi kepada pegawai kantor maupun masyarakat Kelurahan Silaing Bawah Kota Padang Panjang.
\end{abstract}

Kata Kunci: E-Government, E-Kelurahan, Efektivitas Program 


\begin{abstract}
Research carried out moved from the existence of problems in the implementation of the e-kelurahan program, where in its implementation there were still many people who had not used the e-kelurahan program to manage their administrative needs. This study aims to determine the effectiveness of the implementation of the e-kelurahan program in Silaing Bawah Padang Panjang City in providing services to the community, what are the obstacles faced in implementing the e-kelurahan program in Silaing Bawah Village, Padang Panjang City. And efforts to overcome the obstacles faced. The research method used is a qualitative descriptive research method. The data sources used are primary data and secondary data obtained through interviews and documentation studies. Test data validity is done by data triangulation technique. The results of this study indicate that overall, the effectiveness of the implementation the e-kelurahan program in Silaing Bawah village Padang Panjang city is based on program understanding indicators, on target, on time, achieving goals, and real changes have gone well, but have not been fully effective. This can be seen from the lack of socialization carried out by the staff of the kelurahan office and the community itself as well as the lack of utilization of the e-kelurahan program by the community. The obstacles faced were the lack of implementation the program by office employees and a lack of community satisfaction with the program. And to overcome these obstacles, the Government will then carry out socialiszation to the office employees and the community in Silaing Bawah Village, Padang Panjang City.
\end{abstract}

\title{
Keywords: e-government, e-kelurahan, program effectiveness
}

\section{A. Pendahuluan}

Kemajuan ilmu informasi dan komunikasi memberikan dampak yang signifikan dalam kehidupan masyarakat pada saat sekarang ini. Telah sangat banyak kita temui adanya pemanfaatan teknologi komunikasi dan informasi dalam kehidupan sehari-hari, termasuk pemanfaatan teknologi dalam sistem Pemerintahan. Dimana dalam sistem Pemerintahan, pemanfaatan teknologi komunikasi dan informasi dilakukan dengan adanya penerapan sistem Pemerintahan elektronik atau yang lebih dikenal dengan sebutan $E$ government. Menurut (Risnandar, 2014) e-government adalah bentuk dari paradigma baru dalam pelaksanaan pemerintahan elektronik yang bertujuan untuk menciptakan keterbukaan mengenai informasi publik.

Pemanfaatan teknologi komunikasi dan infomasi tidak hanya dilakukan oleh Pemerintah Pusat saja, namun juga dilakukan oleh Pemerintah 
Daerah termasuk Pemerintah Daerah Kota Padang Panjang. Untuk meningkatkan pelayanan kepada masyarakat, Pemerintah Kota Padang Panjang menciptakan inovasi baru sebagai upaya untuk meningkatakn kualitas pelayanan publik dengan memanfaatkan teknologi yang ada. Dalam upaya untuk meningkatkan kualitas pelayanan publik dengan memanfaatkan teknologi komunikasi dan informasi, maka Pemerintah Kota Padang Panjang menciptakan inovasi pelayanan dalam bentuk program $e$-kelurahan.

Kota Padang Panjang merupakan kota yang pertama kali menerapkan program $e$-kelurahan di Provinsi Sumatera Barat. E-kelurahan merupakan bentuk pengembangan $e$ government dalam sistem pemerintahan Indonesia, yang bertujuan untuk mempermudah masyarakat dalam mengurus suratsurat dan keperluan administrasinya dalam wilayah kerja Kelurahan. Menurut (Pratami et al., 2016), dikatakan bahwa E-kelurahan merupakan sebagian dari pengembangan e-government yaitu layanan berbasis Information, Communication, and Technology (ICT) dalam pengelolaan administrasi data kependudukan yang digunakan untuk mempermudah masyarakat dalam proses penerbitan surat.
Program $e$-kelurahan ini sendiri diterapkan sejak 2 tahun yang lalu di Kelurahan Silaing Bawah Kota Padang Panjang, tepatnya pada September 2016 silam. Pemerintah Kota Padang Panjang sendiri sangat mendukung program $e$-kelurahan dalam meningkatkan pelayanan publik di Kelurahan Silaing Bawah, sosialisasipun mulai dilaksanakan sejak penerapannya tahun 2016 lalu. Sosialisasi telah dilakukan diberbagai kalangan masyarakat, mulai dari tokoh masyarakat, pemuda, dan masyarakat lainnya dalam kawasan kelurahan Silaing Bawah. Dalam penerapannya $e$ kelurahan diharapkan bisa memberikan dampak positif bagi masyarakat dan Pemerintah. Diharapkan program $e$-kelurahan bisa membantu efisiensi dan efektifitas birokrasi Pemerintahan yang tidak memerlukan banyak tenaga dan biaya.

Untuk saat ini, Kota Padang Panjang telah menerapkan program $e$ kelurahan disetiap Kelurahan yang ada di Padang Panjang, termasuk Kelurahan Silaing Bawah, Kecamatan Padang Panjang Barat. Program $e$-kelurahan sendiri diterapkan mengingat banyaknya masyarakat Kota Padang Panjang khususnya masyarakat Kelurahan Silaing Bawah yang bekerja sebagai Pegawai Negeri Sipil, sehingga 
dengan adanya program $e$-kelurahan masyarakat tidak harus datang langsung ke kantor untuk mengurus keperluannya, cukup dengan membuka website yang bisa dilakukan dimanapun mereka berada. Hal ini diharapkan mampu membantu masyarakat untuk mempermudah mengurus keperluan administrasinya.

Program $\quad e$-kelurahan sendiri bertujuan untuk meningkatkan kualitas pelayanan kepada masyarakat, sehingga bisa mempermudah Pemerintah dalam memberikan pelayanan kepada masyarakat. Selain itu, progam $e$ kelurahan juga bertujuan untuk memberikan kemudahan bagi masyarakat dalam pengurusan suratsurat dan keperluan administrasi lainnya, serta bisa menghemat waktu dan biaya dalam pengurusan keperluannya. Namun pada kenyataannya, penerapan program $e$ kelurahan tersebut sekarang tidak berjalan lagi sesuai semestinya. Hal ini dikarenakan terjadinya penurunan jumlah masyarakat yang memanfaatkan program $e$-kelurahan untuk mengurus keperluannya, masyarakat Kelurahan Silaing Bawah pada saat ini lebih banyak datang langsung ke Kantor Kelurahan. Hal ini mengindikasikan bahwa penerapan program $e$ kelurahan dirasa belum efektif di
Kelurahan Silaing Bawah Kota Padang Panjang.

Berikut adalah tabel perbandingan pemanfaatan program $e$-kelurahan dan masyarakat yang menggunakan cara manual di Kelurahan Silaing Bawah Kota Padang Panjang.

Tabel 1.1 Perbandingan Pemanfaatan E-kelurahan dan Cara Manual di Kelurahan Silaing Bawah Tahun 2018

\begin{tabular}{||c||c||c|c||}
\hline Tahun & Penduduk & $\begin{array}{c}\text { E- } \\
\text { kelurahan }\end{array}$ & Manual \\
\hline \hline 2016 & 581 & 436 & 145 \\
\hline 2017 & 1268 & 380 & 888 \\
\hline 2018 & 876 & 88 & 789 \\
\hline
\end{tabular}

Sumber: Arsip Kantor Kelurahan Silaing Bawah Tahun 2018

Tentunya ini tidak dapat disimpulkan dengan begitu saja, diperlukan adanya penelitian lebih lanjut lagi mengenai efektivitas penerapan program $e$-kelurahan di Kelurahan Silaing Bawah sehingga nantinya bisa menemukan fakta yang sesungguhnya. Untuk itu, peneliti berniat untuk melakukan penelitian lebih lanjut lagi mengenai efektivitas penerapan program $e$-kelurahan di Kelurahan Silaing Bawah dengan judul "Efektivitas Penerapan Program E-kelurahan di Kelurahan Silaing Bawah Kota Padang Panjang" 
Elektonic Government merupakan bentuk dari penggunaan teknologi informasi yang dilakukan oleh Pemerintah untuk meningkatkan pelayanan publik yang berorientasi kepada masyarakat. Menurut Mary Maureen Brown (Deddy Mulyadi, 2016) konsep E-Government merupakan pemanfaatan kemajuan ilmu teknologi terutama aplikasi internet berbasis web untuk meningkatkan akses pemerintah kepada warga negara, rekanan bisnis, pekerja, dan etnitas pemerintah yang lain.

Dengan demikian, dapat disimpulkan bahwa electronic government (eGov) merupakan penggunaan jaringan internet untuk mengakses berbagai keperluan administrasi pemerintahan yang bertujuan untuk meningkatkan pelayanan kepada masyarakat. Dengan adanya pemanfaatan e-government diharapkan mampu memberikan efisiensi, efektivitas, akuntabilitas, dan transparansi pelayanan publik.

Aspek penunjang keberhasilan $e$ government dikemukakan oleh $\mathrm{Ni}$ Nyoman Dewi Pancarani, S. S., M. Si dalam jurnal (Oktavya, 2015) yaitu sebagai berikut:
1) Kesiapan Sumber Daya Manusia
2) Partisipasi

3) Ketersediaan dan konsistensi anggaran

4) Keamanan

5) Infrastruktur

Program $e$-kelurahan merupakan bentuk inovasi baru dalam pengembangan $e$-government. Menurut (Yusuf, 2017) $e$-kelurahan merupakan suatu inovasi yang berfungsi untuk memperoleh dan mempercepat pelayanan, pengelolaan (manajemen) terhadap administrasi di kantor kelurahan. Aplikasi $e$ kelurahan bersifat online dan lebih menekankan pada adanya manajemen administrasi yang baik.

Adapun tujuan dari penerapan program $e$-kelurahan yaitu untuk meningkatkan pelayanan publik, sehingga nantinya bisa memberikan rasa puas terhadap masyarakat itu sendiri. Selain itu, program $e$ kelurahan juga betujuan untuk mempersingkat waktu dalam pengurusan surat-surat dan keperluan administrasi lainnya yang diperlukan oleh masyarakat.

Pada konsep efektivitas dapat dijadikan sebagai suatu ukuran yang menyatakan seberapa jauh target telah tercapai melalui alternatif yang telah ditentukan. Efektivitas adalah menggambarkan seluruh siklus mulai dari input, proses, dan output yang mengacu pada hasil guna dari suatu organisasi, program atau kegiatan 
yang menyatakan sejauhmana tujuan telah tercapai, serta ukuran berhasil tidaknya suatu organisasi mencapai tujuan-tujuannya. Dilakukan secara efektif dimana dalam proses pelaksanaannya senantiasa menampakkan ketepatan antara harapan yang kita inginkan dengan hasil yang dicapai. Dapat dikatakan efektif apabila hasil yang dicapai semakin mendekati target yang telah ditentukan sebelumnya.

Adapun pengukuran efektivitas menurut Sutrisno 2007, yaitu:

1) Pemahaman Program

2) Tepat Sasaran

3) Tepat Waktu

4) Tercapainya Tujuan

5) Perubahan Nyata

\section{B. Metode Penelitian}

Adapun metode penelitian yang digunakan yaitu Metode penelitian kualitatif. Metode penelitian kualitatif merupakan bentuk metode penelitian dimana peneliti sendiri bertindak sebagai instrumen kunci dari kegiatan penelitian. Bogdan dan Taylor dalam (Moleong, 2006) mendefinisikan metodologi kualitatif sebagai prosedur penelitian yang menghasilkan data deskriptif berupa kata-kata tertulis atau lisan dari orang-orang dan perilaku yang dapat diamati.
Jenis penelitian yang digunakan dalam penelitian ini adalah deskriptif dengan pendekatan kualitatif. metode deskriptif dalam (Moleong, 2006) yaitu metode penelitian yang berisi kutipan-kutipan data untuk memberi gambaran penyajian laporan, bisa berasal dari naskah wawancara, catatan lapangan, foto, videotape, dokumen pribadi, catatan atau memo, dan dokumen resmi lainnya.

Penelitian ini dilakukan di Kelurahan Silaing Bawah Kota Padang Panjang. Alasan memilih Kelurahan Silaing Bawah karena Kelurahan Silaing Bawah merupakan Kelurahan pertama yang menerapkan program $e$-kelurahan di Kota Padang Panjang. Dan disana juga ditemukan adanya beberapa permasalahan yang berkaitan dengan penerapan program $e$-kelurahan.

Jenis data yang akan diambil dalam penelitian ini adalah: 1) efektivitas penerapan program $e$-kelurahan di Kelurahan Silaing Bawah Kota Padang Panjang, apakah sudah sesuai dengan apa yang ditargetkan. 2) kendala. 3) upaya dalam mengatasi kendala. Informan dalam penelitian ini dipilih dengan teknik purposive sampling, yaitu menentukan informan dengan pertimbangan atau kriteria-kriteria tertentu yang dipandang dapat memberikan data secara maksimal (Moleong, 2006). 
Selain itu, untuk menentukan masyarakat yang akan dijadikan sebagai informan dalam penelitian akan digunakan teknik accidental sampling, yaitu teknik penentuan informan berdasarkan siapa saja yang ditemui secara kebetulan di lapangan.

Data primer dalam penelitian ini diperoleh melalui wawancara dan observasi. Sedangkan data sekunder diperoleh melalui studi dokumentasi. Keabsahan data dilakukan dengan teknik triangulasi sumber. Teknik triangulasi digunakan untuk mencocokkan sumber yang peneliti peroleh dari wawancara dan dokumentasi. Proses analisis data dimulai dari pengumpulan data, reduksi data, penyajian data, penyimpulan dan verifikasi, serta kesimpulan akhir.

\section{Hasil dan Pembahasan}

Efektivitas merupakan perbandingan antara target dengan hasil yang telah dicapai. Dikatakan efektif apabila hasil yang diperoleh semakin mendekati target yang telah ditetapkan. Semakin mendekati target, maka dapat dikatakan semakin efektif. Untuk itu diperlukan adanya pengukuran efektivitas yang sesuai dengan sasaran dan tujuan yang hendak dicapai.
Dalam penelitian ini digunakan pengukuran efektivitas program $e$ kelurahan dengan menggunakan indikator pengukuran efektivitas yang dikemukan oleh Sutrisno dalam (Ramadhan, 2018), yaitu:

Pemahaman Program, yaitu sejauhmana masyarakat dan stakeholder lainnya memahami program $e$-kelurahan. (2) Tepat Sasaran, yaitu apa dan siapa sasaran yang akan dituju dalam penerapan program e-kelurahan. (3) Tepat Waktu, yaitu sejauhmana program $e$ kelurahan bisa mempengaruhi waktu dalam pelaksanaan pelayanan di Kantor Kelurahan Silaing Bawah. (4) Tercapainya Tujuan, yaitu melihat apakah program $e$-kelurahan sudah mencapai tujuan yang telah ditetapkan. Penerapan program $e$ kelurahan tidak hanya dilakukan untuk memberikan pelayanan kepada masyarakat, namun juga melihat apakah program $e$-kelurahan sudah membantu masyarakat dan stakeholder lainnya dalam mempermudah pelayanan yang diberikan dan diterima. (5) Perubahan Nyata, yaitu adanya suatu perubahan yang terjadi setelah adanya penerapan program $e$ kelurahan, apa dampak dan pengaruh dari program $e$-kelurahan dalam pelayanan publik.

1. Efektivitas Penerapan Program

a) Pemahaman Program 
Menurut Sutrisno dalam (Ramadhan, 2018) pemahaman program berkaitan dengan sejauhmana kelompok kepentingan atau stakeholder mengetahui dan memahami mengenai program yang diterapkan. Dalam hal ini maka pemahaman program berkaitan dengan sejauhmana masyarakat dan stakeholder lainnya dapat mengetahui dan memahami kegiatan program serta mengenai sosialisasi tentang program e-kelurahan di Kelurahan Silaing Bawah Kota Padang Panjang.

Berdasarkan wawancara yang penulis lakukan dengan pemangku kepentingan terkait dan masyarakat, dapat disimpulkan bahwa pemahaman program $e$-kelurahan sudah efektif, meskipun masih belum dimanfaatkan oleh masyarakat secara optimal. Dari pihak Pemerintah dapat disimpulkan bahwa penerapan program $e$-kelurahan sudah dapat dipahami oleh pegawai kantor. Dan jika dilihat dari aspek masyarakat, maka dapat dilihat bahwa 7 dari 10 masyarakat mengatakan mereka mengetahui dan paham mengenai program $e$-kelurahan, namun belum memanfaatkan program $e$-kelurahan dengan berbagai alasan yang dikemukakan. Meskipun mereka tidak memanfaatkan program $e$ kelurahan, namun dari segi pemahaman program mereka sudah paham mengenai program $e$ kelurahan. Dengan demikian maka dapat dikatakan bahwa aspek pemahaman program sudah efektif dari pihak Pemerintah dan masyarakat.

b) Ketepatan Sasaran

Tepat sasaran dapat diartikan sebagai kesesuaian antara sasaran program dengan tujuan yang telah ditentukan. program yang telah dilaksanakan harus ditujukan kepada sasaran yang kongkret, sehingga proses pelaksanaan program dapat berjalan dengan efektif. Dalam hal ini adapun sasaran yang dituju dalam penerapan program $e$-kelurahan yaitu meningkatkan pelayanan kepada masyarakat, dengan demikian maka sasaran dari penerapan program $e$ kelurahan yaitu masyarakat. Karena pada dasarnya efektifnya suatu program sangat dipengaruhi oleh aspek masyarakat sebagai pengguna dan pemanfaat dari program yang diterapkan.

Dari wawancara yang peneliti lakukan, dapat disimpulkan bahwa dari aspek ketepatan sasaran, program $e$-kelurahan belum efektif. Hal ini karena ditemuinya permasalahan sosialisasi mengenai pemanfaatan program $e$-kelurahan oleh pihak Pemerintah kepada masyarakat Kelurahan Silaing Bawah. Sosialisasi yang dilakukan belum sepenuhnya ditujukan kepada 
masyarakat secara khusus. Hal ini menyebabkan masyarakat tidak sepenuhnya memanfaatkan program $e$-kelurahan.

Dengan demikian maka dapat dikatakan bahwa sosialisasi yang dilakukan oleh Pemerintah belum sepenuhnya tepat sasaran, karena pada dasarnya pengenalan dan sosialisasi program $e$-kelurahan seharusnya lebih menekankan kepada masyarakat. Sehingga masyarakat bisa lebih memahami dan lebih mengerti mengenai program $e$ kelurahan, namun sampai saat ini sosialisasi yang dilakukan belum sepenuhnya terfokus kepada masyarakat secara umum. Hanya dilakukan pada saat ada acara tertentu saja yang diselingi dengan pengenalan dan sosialisasi program $e$-kelurahan.

\section{c) Ketepatan Waktu}

Ketapatan waktu merupakan jangka waktu yang diperlukan dalam penerapan program. Dalam hal ini melihat bahwa sejauhmana program $e$-kelurahan bisa mempengaruhi waktu dalam pelaksanaan pelayanan di Kantor Kelurahan Silaing Bawah. Karena dalam penerapan program $e$ kelurahan diharapkan bisa memberikan kemudahan bagi Pemerintah dalam memberikan pelayanan kepada masyarakat, dan bisa mempermudah masyarakat dalam mengurus keperluannya. Baik itu keperluan untuk mengurus suratsurat maupun keperluan administrasi lainnya.

Dari wawancara yang peneliti lakukan dengan pihak Pemerintah dan masyarakat Kelurahan Silaing Bawah, dapat dipahami bahwa dalam penerapan program $e$-kelurahan sudah bisa memberikan kemudahan dan mempersingkat waktu bagi Pemerintah dalam memberikan pelayanan kepada masyarakat. Namun dari aspek masyarakat, belum bisa dikatakan efektif. Karena waktu yang diperlukan dalam pengurusan surat melalui program $e$ kelurahan tergantung kepada mudah atau tidaknya mengakses program $e$ kelurahan. Jika $e$-kelurahan mudah untuk diakses, maka pengurusan suratnya juga akan mudah. Namun jika waktu yang diperlukan untuk membuka dan mengakses $e$ kelurahan itu lama, maka pengurusan surat juga akan memakan waktu yang lama. Ini tentunya menjadi salah satu alasan kenapa masyarakat tidak ingin memanfaatkan program $e$-kelurahan.

\section{d) Tercapainya Tujuan}

Tercapainya tujuan diukur dari pencapaian tujuan yang telah dilaksanakan. Dalam penerapan progra $e$-kelurahan adapun tujuan yang ingin dicapai yaitu 
mempermudah Pemerintah dalam memberikan pelayanan kepada masyarakat, mepermudah masyarakat dalam pengurusan surat dan keperluan administrasi lainnya, serta mempersingkat waktu dan biaya dalam pengurusan surat oleh masyarakat. Dengan adanya tujuan yang telah ditentukan, efektivitas program $e$-kelurahan dapat diukur dari seberapajauh tujuan yang ditentukan sudah tercapai sampai saat ini.

Dari wawancara yang peneliti lakukan, dapat dipahami bahwa pencapaian tujuan dari penerapan program $e$-kelurahan belum sepenuhnya efektif. Hal ini dilihat dari jumlah masyarakat yang mengurus surat secara manual lebih tinggi dibandingkan dengan menggunakan program $e$-kelurahan. Karena dikatakan efektif apabila jumlah masyarakat yang memanfaatkan program $e$-kelurahan lebih banyak dari masyarakat yang menggunakan cara manual. Disini sapat dilihat bahwa pencapain tujuan dari program $e$-kelurahan yang diharapakan bisa mempermudah masyarakat dalam pengurusan suratsurat dan keperluan administrasi lainnya dirasa tidak efektif. Sehingga tujuan untuk menghemat waktu dan biaya juga tidak bisa dikatakan efektif dalam penerapan program $e$ - kelurahan di Kelurahan Silaing Bawah Kota Padang Panjang.

e) Perubahan Nyata

Perubahan nyata melihat bahwa sejauhmana pelaksaan program dapat memberikan efek atau dampak serta perubahan yang nyata bagi masyarakat. Dalam hal ini maka perubahan nyata melihat sejauhmana program $e$-kelurahan memberikan dampak atau perubahan nyata dalam memberikan pelayanan kepada masyarakat. Apakah masyarakat merasakan adanya perubahan atau dampak yang mereka rasakan setelah adanya penerapan program ekelurahan.

Dan dari wawancara yang peneliti lakukan dapat diketahui bahwa tidak adanya dampak dari penerpan program e-kelurahan yang dirasa signifikan oleh masyarakat dan Pemerintah. Hal ini dikarenakan waktu yang diperlukan dalam pengurusan surat juga belum bisa dikatakan efektif. Penerapan program $e$-kelurahan juga belum memberikan perubahan yang signifikan terhadap pelayanan kepada masyarakat. masyarakat juga masih memilih untuk datang langsung ke kantor kelurahan untuk mengurus surat. Dengan demikian maka dapat dikatakan bahwa penerapan program e-kelurahan tidak memberikan dampak yang signifikan dalam pelayanan masyarakat. 
2. Kendala Dalam Penerapan

\section{Program $E$-Kelurahan}

Penerapan program $e$-kelurahan bertujuan untuk memberikan kemudahan bagi Pemerintah maupun masyarakat dalam melakukan pelayanan. Namun dalam penerapannya, tentunya masih terdapat kendala atau hambatanhambatan yang dirasakan, baik itu dari pihak Pemerintah maupun dari masyarakat itu sendiri. Kendala merupakan segala halangan atau rintangan yang dihadapi oleh organisasi atau perusahaan dalam mencapai tujuan yang hendak dicapai.

Hansen dan Mowen dalam (Haksama, 2016) mengelompokkan jenis kendala atau constraint berdasarkan asalnya menjadi dua, yaitu: kendala internal dan kendala eksternal.

Dan dari wawancara yang peneliti lakukan, adapaun kendala dalam penerapan program $e$-kelurahan di Kelurahan Sialing Bawah yaitu:

1. Kendala internal, dirasakan dari dalam organisasi. Dimana disini organisasi yang dimaksud yaitu pihak Pemerintah sebagai pihak yang menerapkan program $e$ kelurahan. Dari segi internal, kendala yang dihadapi yaitu pemahaman Sumber Daya Manusia mengenai pengaplikasian program $e$ kelurahan di Kelurahan Silaing Bawah, sehingga pengaplikasian program e-kelurahan lebih banyak dilakukan oleh operator kantor Kelurahan.

2. Kendala Eksternal, yaitu kendala yang dihadapi dari luar organisasi. Disini adapun kendala yang dihadapi dalam penerapan program e-kelurahan yaitu kurangnya kepuasan masyarakat terhadap program ekelurahan dan kurangnya sosialisasi yang ditujukan kepada masyarakat secara khusus. Sehingga hal ini menyebabkan masyarakat tidak ingin memanfaatkan program ekelurahan di Kelurahan Silaing Bawah Kota Padang Panjang.

Untuk mengatasi kendala yang dihadapi tentunya harus diimbangi dengan adanya upaya yang dilakukan untuk mengatasi kendala yang ada. Dalam penerapan program $e$ kelurahan tentunya terdapat upaya yang dilakukan oleh Pemerintah untuk mengatasi kendala yang dihadapi. Dari wawancara yang peneliti lakukan, adapun kendala yang dilakukan oleh Pemerintah dalam mengatasi kendala yang dihadapi yaitu Pemerintah akan melakukan sosialisasi lebih lanjut lagi mengenai program $e$-kelurahan di Kelurahan Silaing Bawah Kota 
Padang Panjang, baik itu sosialisasi kepada pegawai kantor maupun sosialisasi lebih lanjut kepada masyarakat secara khusus. Hal ini dilakukan untuk meningkatkan pehaman pegawai dan masyarakat mengenai program $e$-kelurahan itu sendiri. Sehingga nantinya penerapan program $e$-kelurahan bisa berjalan dengan lancar dan efektif.

\section{Penutup}

Berdasarkan hasil temuan dan hasil pembahasan yang telah dilakukan peneliti dapat menarik kesimpulan sebagai berikut: Kelurahan Silaing Bawah sebagai salah satu instansi pemerintah yang sudah menjalankan Program e- Kelurahan sebagai bentuk inovasi pelayanan publik dalam bidang $e$ goverment sudah baik namun belum efektif, ditandai dengan belum terwujudnya beberapa indikator ke efektifitasan suatu program. Program $e$ kelurahan sudah membantu dalam beberapa kondisi dari segi pengurursan surat oleh pihak instansi pemerintah kelurahan silaing bawah, namun belum dirasakan maksimal manfaatnya oleh masyarakat kelurahan silaing bawah sebagai masyarakat pengunna program $e$ kelurahan. Kendala yang dihadapi oleh Kelurahan Silaing Bawah dalam menerapkan program $e$ - kelurahan adalah kurangnya tingkat kepuasaan atas inovasi pelayanan publik dalam hal pengurusan dokumen-dokumen yang di berikan melalui program $e$ Kelurahan yang kedua adanya unsur eksternal seperti jaringan dan cuaca yang menghambat kinerja program $e$ Kelurahan. Sehingga menyebabkan masyarakat pengguna $e$ - kelurahan beralih lagi ke pengurusan surat secara manual hal ini di tandai dengan turunnya angka masyarakat pengguna $e$ kelurahan di kelurahan silaing bawah dari tahun ke tahun sejak program tersebut dikeluarkan.

Untuk mengatasi kendala yang terjadi pemerintahkelurahan silaing bawah berupaya melakukan sosialisasi secara intens dan menyediakan waktu khusus untuk mengenalkan kembali tujuan dari diadakannya program $e$ kelurahan melalui pengoptimalan sosialisasi.

\section{Daftar Pustaka}

Deddy Mulyadi, D. (2016). Administrasi Pubik Untuk Pelayanan Publik. Bandung: Alfabeta.

Haksama, S. P. L. dan S. (2016). Penerapan Theory Of Constraint Pada Kepuasan Kerja Karyawan Rumah Sakit Mata Undaan Surabaya, 4(2).

Moleong, L. J. (2006). Metode Penelitian Kualitatif. Bandung: PT Remaja Rosdakarya.

Oktavya, A. A. (2015). Penerapan (Electronic Government) EGovernment Pada Kantor 
Pelayanan Pajak Pratama

Dalam Pemberian Pelayanan

Di Kota Bontang. eJurnal Ilmu

Pemerintahan, 3(3), 14331447.

Ramadhan, T. (2018). Efektivitas

Program BPNT Terhadap

Peningkatan Kesejahteraan

Masyarakat Kecamatan

Tampan Pekanbaru. JOM

FISIP, 5(2), 1-14.

Risnandar. (2014). Analisis egovernment dalam peningkatan pelayanan publik pada dinas komunikasi dan informatika provinsi sulawesi tengah. $E$ Jurnal Katalogis, 2(7), 192199.

Yusuf, M. N. (2017). Studi Tentang Inovasi Manajemen Dan Administrasi Di Tingkat Kelurahan (Studi Penggunaan e-Bukuan dan e-Kelurahan di Kelurahan Bukuan Kecamatan Palaan. E-Journal Pemerintahan Integratif, 5(4), 529-538. 